\title{
Breast cancer protection by genomic imprinting in close kin families
}

\author{
Srdjan Denic ${ }^{1 *}$ and Mukesh M. Agarwal ${ }^{2}$
}

\begin{abstract}
Human inbreeding generally reduces breast cancer risk (BCR). When the parents are biologically related, their infants have a lower birth weight due to smaller body organs. The undersized breasts, because of fewer mammary stem cells, have a lower likelihood of malignant conversion. Fetal growth is regulated by genomically imprinted genes which are in conflict; they promote growth when derived from the father and suppress growth when derived from the mother. The kinship theory explicates that the intensity of conflict between these genes affects growth and therefore the size of the newborn. In descendants of closely related parents, this gene clash is less resulting in a smaller infant. In this review, we elucidate the different mechanisms by which human inbreeding affects BCR, and why this risk is dissimilar in different inbred populations.
\end{abstract}

Keywords: Public health, Mate selection, Epigenetics, Homozygosis, Heterosis, Arabs, Pakistan

\section{Background}

The link between human consanguinity and malignancy is important for understanding carcinogenesis. Cancer has a strong genetic component and human consanguinity, still very common in many parts of the world, increases gene homozygosis. Homozygosis of low penetrance tumor genes, and its frequency in the population, can increase or decrease the risk of cancer [1-6]. Homozygosis of mutated tumor suppressor genes in stem cells with double dose can cause either early abortion or early childhood cancer [7-9]. Consanguinity can lower breast cancer risk (BCR) as homozygosis of mutated DNA-repair genes like BRCA1 and BRCA2, being incompatible with life, are not transmitted to the next generation [10-12]. Homozygotes of abnormal mismatch repair genes (e.g., MLH1, MSH2, MSH6) that cause a severe cancer syndrome, also fail to reproduce [13]. Thus, inbreeding should clear the consanguineous population of these tumor genes and inherited cancer syndromes should be less common in consanguineous (compared to non-consanguineous) populations. However, multiple other factors are involved: parents with a low cancer risk can also produce offspring with a higher

\footnotetext{
* Correspondence: s.denic@uaeu.ac.ae

${ }^{1}$ Department of Medicine, College of Medicine and Health Sciences, United

Arab Emirates University, PO Box 17666, Al Ain, Abu Dhabi, UAE

Full list of author information is available at the end of the article
}

cancer risk by negative heterosis, i.e., offspring exhibit more negative qualities than their parents [14-16]. Thus, the cumulative (and often competing) outcome of different consanguinity-cancer models is difficult to predict due to varying frequency of the different cancer genes and varying environmental aspects involved in carcinogenesis in different populations. As a result, both an increase and a decrease in risk of different cancers has been reported in different consanguineous populations [17-27]. Similarly, inconclusive links have been reported between cancer risk and autozygosity (measured by size of the regions of homozygosis in human genome) in different world populations [28-34].

The various studies on BCR in inbreeding families, similar to other types of cancer, have also produced contradictory results. BCR is lower in Arab inbreeding families than non-inbreeding families [18-23]. However, the BCR is increased in inbreeding families from Pakistan [24-27]. In this review, we deliberate how human consanguinity can lower BCR through genomic imprinting and why some other mechanisms of inbreeding may increase it.

\section{Human consanguinity: Prevalence, types of marriages and measures of relatedness}

Human consanguinity is more frequent than generally appreciated. Worldwide, 1.1 billion of people have consanguineous parents [35]. Such unions are most 
common in the developing societies of North Africa, the Middle East and South Asia. In these populations, 10\% to $50 \%$ of all marriages are between close kin: first cousins, double first cousins, first cousins once removed and second cousins. Since the latter unions do not increase biological risks of inbreeding, they are not considered consanguineous. Half of all consanguineous marriages are between first cousins; a woman can be married to only one of her four first cousins: father's brother's son (FBS), father's sister's son, mother's brother's son and mother's sister's son (Fig. 1). The Arab world comprises of 22 nations of the Middle East and North Africa in which people speak the same language (Arabic) and share the same religion (Islam); however, their genetic heritage is much less uniform. Arab families, in contrast to non-Arab families, arrange FBS unions half the time instead of the expected one fourth. The preference for FBS marriage is a cultural trait universal among Arabs which mandates that every woman's marriage should be approved by her paternal uncle [36, 37]. Similarly, in double first cousin unions, there are two possible types of cousins and, in first cousin once removed unions there are eight different types of cousins (Table 1). In contrast to first cousin unions, the frequencies of different cousin choices in later two types of unions are unknown. The biological closeness of spouses is defined by the coefficient of relatedness $(R)$ which indicates the fraction of autosomal genes two individuals share by common descent (Table 1). The coefficient of inbreeding $(F)$ is a fraction of autosomal genes that are homozygous by common descent and measures the risk of genetic harm in offspring of biologically related individuals $(F=$ $R / 2$ ). In any population, the mean $R$ correlates with the consanguinity rate, but former is a more precise an indicator of biological closeness.

\section{Parental consanguinity and breast cancer}

The age-standardized incidence of breast cancer is inversely related to the rate of consanguinity (Fig. 2). In five studies from Arab countries, parental consanguinity was protective against breast cancer. In two studies involving the native population of United Arab Emirates, a) BCR in women born to consanguineous parents was half $(50 \%)$ compared to women of non-consanguineous parents; this protective effect was greater among women less than 50 years old $(p=0.02)$ [18], and b) breast cancer patients had a lower mean coefficient of inbreeding $(p=0.19)$ and their parents were less often first and double first cousins $(p=0.09)$ than the parents of noncancer controls [19]. In another case-controlled study from Qatar, breast cancer patients had a lower mean coefficient of inbreeding than controls $(p=0.0125)$ [21]. In Morocco, both consanguinity rate and mean coefficient of inbreeding were lower among breast cancer patients

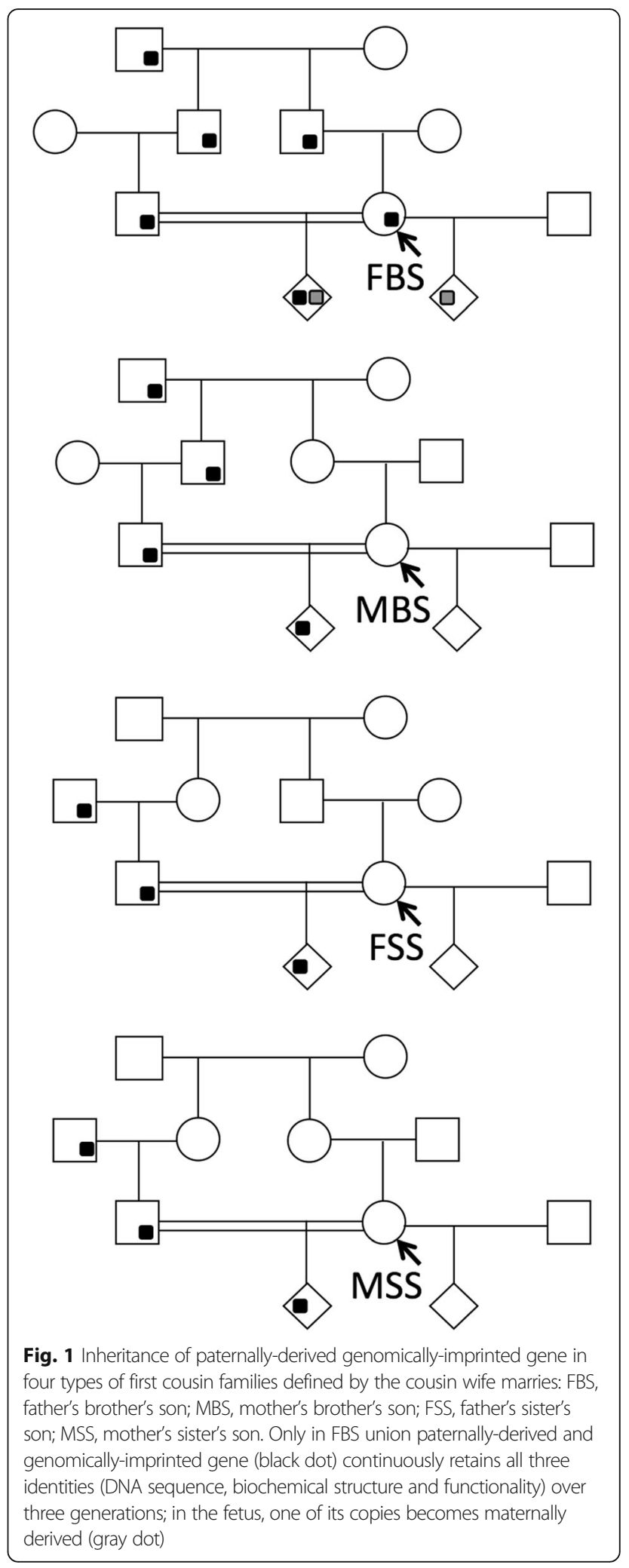

than matched controls [22]. Similarly, a statistically significant protective effect of parental consanguinity against breast cancer was reported from Tunisia [23]. 
Table 1 Coefficients of relatedness by common descent of autosomal genes $(R)$ and genomically imprinted genes inherited from father $\left(R_{p}\right)$ and mother $\left(R_{m}\right)$ in non-kin and close-kin families

\begin{tabular}{llll}
\hline Marriage & Women units with & $R$ & $R_{p}$ \\
\hline Random & Non-kin & & $R_{m}$ \\
Double first cousin & Father's brother's and mother's sister's son & 0.25 & 0.25 \\
First cousin & Father's sister's and mother's brother's son & 0.25 & 0.125 \\
& Father's brother's son & 0.125 & 0.125 \\
& Father's sister's son & 0.125 & 0.0625 \\
Mirst cousin once removed & Mother's brother's son & 0.125 & 0.125 \\
& Mother's sister's son & 0.0625 & 0.0625 \\
& Father's paternal uncle's son & 0.0625 & 0.0625 \\
& Father's paternal aunt's son & & \\
& Father's maternal uncle's son & 0.0625 & 0.0625
\end{tabular}

One possible explanation for this observation is the protective effect of homozygosis of some low penetrance breast cancer gene(s) common in all Arab populations. Indeed, in a study from Tunisia, homozygote of one variant of the $P 53$ gene was associated with a lower BCR [38]. However, the same genotype in the Saudi population was reported to increase the BCR [39]. In Arab populations only a few specific and more of commonly shared variants of breast cancer susceptibility genes have been identified [40]. In theory, another possibility is that consanguinity protects against breast cancer by decreasing the number of $B R C A 1$ and $B R C A 2$ cancer cases as homozygotes of these genes are early aborted [10-12]. In Arabs, these germline mutations are few and those specific for the population have not unequivocally

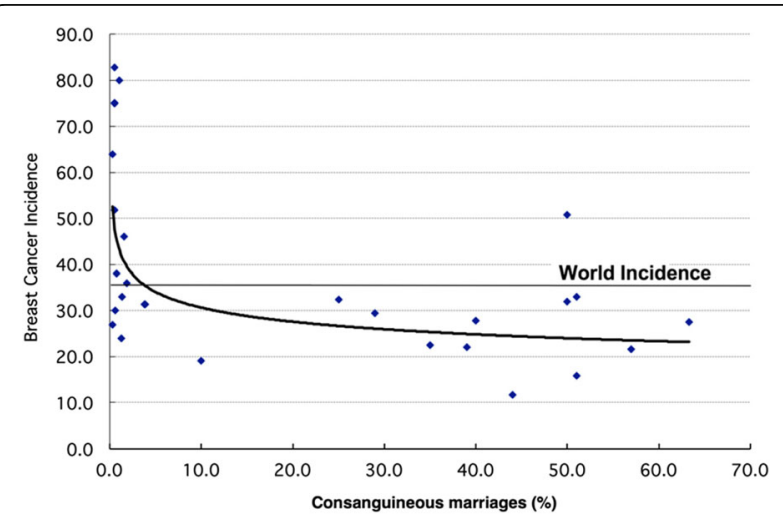

Fig. 2 Age-standardized incidence of breast cancer and rate of consanguinity reported from 28 countries. The outlier (incidence 50, consanguinity 50) country is Pakistan. Adapted from reference [12] proven to be carcinogenic [41, 42]; hence, the breast cancer protection by parental consanguinity is largely unexplained.

In contrast to the decrease in risk, breast cancer in Pakistan positively correlates with parental consanguinity [24-27]. Pakistan is a country with an unusually high incidence of breast cancer (outlier in Fig. 2); among its nationals, the incidence of breast cancer is significantly higher compared to its neighboring countries [43]. A high frequency of $B R C A 1$ and BRCA2 mutations has been proposed to explain these epidemiological findings. However, most of the gene variants are unique to Pakistan, and they have not been convincingly shown to be carcinogenic [24-26]. In addition, consanguinity should protect against breast cancer caused by $B R C A 1$ and $B R C A 2$ which is not a case in this population. In the absence of any obvious environmental risk factor for breast cancer that contrasts Pakistan from its neighbors, a higher frequency of low penetrance cancer genes that increase cancer risk in homozygotes is a more likely explanation. Until now, however, only a few of the known low penetrance breast cancer genes have been studied and none of them can explain the high breast cancer rates in both general population and daughters of consanguineous parents $[2,26]$. In this population, however, new mutations of CHEK2 gene, which moderately increases risk of breast cancer in heterozygotes, were found in rare patients from a few tested ethnic groups $[44,45]$. The homozygotes of CHEK2 mutation are at higher risk of breast cancer development than heterozygote which could explain increased BCR in both general population and daughters of consanguineous parents 
[46]. Nonetheless, a very low frequency of this gene cannot explain high rate of breast cancer in Pakistan.

Another possible mechanism that could increase breast cancer rate among Pakistani women is negative heterosis $(\mathrm{NH})$ [47]. This phenomenon of $\mathrm{NH}$ was noticed almost a century ago in studies of crossing and back crossing of different inbred subspecies of animals which produced offspring with a higher cancer rates than in both parents [14-16]. NH, in contrast to positive heterosis $(\mathrm{PH})$ (hybrid vigor), signifies that the offspring have more negative qualities than their parents. Recently, it has been shown that heterosis is the result of disrupted genomic imprinting in the offspring of two subspecies of inbred parents [48]. In humans, possible examples of $\mathrm{PH}$ are bigger daughters from mixed marriages (as seen in one tribal region of India), and NH has been proposed as a cause of the exceptionally high incidence of breast cancer in Pakistan [47, 49]. The hypothesis is based on the fact that after a long history of inbreeding in numerous kinship groups (tribes, biradaris, castes) in the region, there was a sudden and violent migration of unprecedented proportions. In 1947, when the Republic of Pakistan was formed, members of inbred groups were forcefully mixed producing inter-group unions that, like $\mathrm{NH}$ in animal studies, could contribute to the extra breast cancer in this population. In short, despite the many hypotheses, the reasons for the higher rates of breast cancer in Pakistan, overall and in consanguineous families, remain largely undetermined.

\section{Parental consanguinity and newborn size}

The lower newborn weight in consanguinity is a less well known phenomenon that remains largely unexplained. In a large $(n=10,289)$ and well-controlled study, infants of consanguineous parents were $1.8 \%$ smaller (than newborns of non-consanguineous parents) [50]. In this same study, a review of 11 previous studies showed that in ten of them the babies of consanguineous parents were, on an average, 20 to $221 \mathrm{~g}$ smaller. This difference was statistically significant in four studies; in the remaining studies, where the results did not achieve statistical significance, the nutritional deprivation was pronounced, the sample size was small and covariates of fetal growth were not controlled. In similar studies from Turkey, inbred newborns were not smaller but inbred school-agedmales (females were not studied) were significantly smaller than non-inbred controls [51, 52]. In all these consanguinity studies, newborns with congenital disorders were excluded from the analysis.

\section{The importance of newborn size}

In general, a newborn's size at birth (i.e., the weight, the length and the head circumference) is determined by both genetic and environmental factors [53]. In one study, causes of variation in birth size was estimated to be as follows: fetal genes, $30 \%$; maternal genes, $20 \%$; environmental factors, 15\%; and unknown factors, $35 \%$ [54]. The mother's height, weight, and weight at birth are stronger determinants of the baby size than the same parameters of the father. Also, many environmental factors are involved like birth order and, during pregnancy, mother's illnesses, caloric intake and use of alcohol, tobacco and hormones [54, 55]. Any study addressing a potentially new cause affecting fetal growth must account for the effects of multiple independent cofounders determining newborn size.

From an evolutionary perspective, bigger individuals survive better than smaller ones, and the birth size correlates with body size during adulthood [54]. From a medical perspective, smaller birth size carries an increased risk of chronic nutritional disorders (obesity, diabetes mellitus type 2, fatty liver, hypertension, cardiovascular diseases) and, in women, a decreased risk of premenopausal breast cancer $[55,56]$.

\section{Birth size and breast cancer}

The neonatal birth size is a well-established risk factor for breast cancer. Studies during the last two decades, from several countries, have consistently shown that birth weight and birth length positively correlate with breast cancer in women $<50$ years old [57-63]. Bigger babies have larger mammary glands and the number of mammary stem cells is proportional to its size [64-66]. A denser shadow of the breast radiogram is associated with a higher mammary gland mass and a higher BCR [67]; furthermore, bigger babies have a higher number of circulating hematopoietic stem cells [68]. The newborn size and the number of stem cells positively correlate with blood levels of several growth promoting hormones and the expression of at least two genomically imprinted genes that affect fetal growth: positively with insulin-like growth factor 2 (IGF-2) (which is expressed when inherited from father and inactivated when inherited from mother), and negatively with PHLDA2 (which is expressed when inherited from mother and genomically imprinted when inherited from father) [69-75]. In short, studies have established a plausible link between the expression of genomically imprinted genes and the risk of malignant transformation in the breast.

\section{Genomically imprinted genes and genetic conflict theory}

The change in gene expression (without the change in DNA nucleotide sequence) is produced by methylation, histone modification, and small RNA interference (imprinting). Generally, with few exceptions, imprinting inactivates genes. Genomic imprinting is a special form of gene inactivation depending on parent from whom it 
originates. As a rule, a gene in the fetus if inherited from mother is suppressed while the same gene if inherited from father is expressed. This results in mono-allelic inheritance and, in effect, transforms one into two genes, each with identical DNA nucleotide sequence but with different biochemical structure (e.g., with methyl groups or without methyl groups) and function (decreased or increased expression) depending on parent of origin. In humans, genomic imprinting is confined to about 100 genes that regulate cell proliferation during fetal and early postnatal development, behavior and cognition, and are expressed mostly in the placenta and the brain $[76,77]$. The evolution of genomic imprinting is explained by the kinship theory [78-81].

\section{Kinship (genetic conflict) theory of genomic imprinting}

The theory of genomic imprinting (also called genetic conflict theory) posits that, in mammals, the genomic imprinting of genes is a consequence of the interactions between the fetus, the mother, the father and their genes, as follows: a) both maternal- and paternal-derived developmental genes regulate growth of the fetus; b) the mother provides disproportionally more resources for the offspring's growth than the father; c) mothers can have offspring from more than one male (polyandry). Bigger babies survive better but they also utilize more resources from the mother, which could lower her fitness by decreasing her resources available for future offspring. To conserve her resources and maximize fitness, mother's growth promoting genes are suppressed. On other hand, the father's genes are expressed to promote growth as this increases the odds of their survival due to a bigger baby. In short, the maternally-derived and paternally-derived genes in the fetus are in conflict about how much growth to promote as this determines the number of their copies in future generations due to a) asymmetry of biological investments in their progeny and b) polyandry which creates different future life trajectories of their gene copies [78-81]. In other words, genomic imprinting emerged during evolution as a mechanism which increases the inclusive fitness of genes. Thus, anything that would affect polyandry is expected to affect the intensity of conflict between genomically imprinted genes and size of the fetus. In one animal study, female rats mated with three males produced bigger pups than females mated with one male [82]. Likewise, in humans, anything that increases inclusive fitness is expected to decrease the intensity of gene conflict and produce smaller babies.

\section{Genetic conflict is lower in consanguineous families}

In a first cousin marriage, the wife carries 0.125 of autosomal genes of her husband by common descent. In future, if she conceives a child with another man, that child would carry 0.0625 of the genes of her current husband, her first cousin and the child's uncle. In her current child, half of those 0.0625 genes are identical by common descent (Fig. 1). In contrast, in a non-cousin (random mate) marriage, none of the genes of current father will be in the other man's child. In close-kin families, therefore, polyandry produces less conflict between parental genes in the fetus. The expected conflict reduction is proportional to $R$ of parents and is shown in Table 1. The kinship theory of genomic imprinting supports the findings of smaller babies in consanguineous families [50]. This theory also predicts that babies of double first cousins will be smaller than babies of first cousins, which in turn are expected to be smaller than babies of first cousins once removed.

However, the genomically imprinted genes are more important for fetal growth than other genes. As per the kinship theory, they are genomically imprinted for that very reason and, consequently, they exert a stronger effect on size of newborns in any consanguineous family. The coefficient of relatedness of the genomically imprinted paternally-derived $\left(R_{p}\right)$ and maternally-derived genes $\left(R_{m}\right)$, however, is different from the nongenomically imprinted genes $(R)$ and are shown in Table 1. Among 14 different kinds of consanguineous families, only in three $R_{p}>0$; in such families, the production of smaller babies is expected. Among four types of first cousin families, likewise, only the FBS family type (more common amongst Arabs) is expected to produce significantly smaller newborns.

\section{Breast cancer protection by parental consanguinity: Summary and conclusion}

Epidemiological observations have helped to uncover many novel mechanisms of carcinogenesis [83]. Several studies suggest that human inbreeding protects against breast cancer. In general, consanguineous parents produce smaller newborns and smaller newborns develop breast cancer less frequently later in life. The reason for smaller infants in close-kin families is elucidated by the kinship theory of genomic imprinting. As per this theory, growth promoting genes inherited from father and mother are in conflict; the intensity of this conflict controls fetal growth and, ultimately, the size of newborn. In the offspring of close-kin marriages, the intensity of genetic conflict is less which results in smaller newborns.

In Arab women, the decrease in BCR by parental consanguinity could be a result of i) decreased gene conflict that is enhanced by a larger number of first cousin marriages of the FBS type, ii) protective effect of homozygosis of some still unidentified breast cancer gene(s), or iii) additive protective effect of both these mechanisms against breast cancer. However, in Pakistan parental 
consanguinity increases BCR. As explained earlier, BCR reduction by decrease gene conflict may be exceeded by increased risk due to the following factors: i) cancer increase due to $\mathrm{NH}$, ii) homozygosis of unidentified breast cancer susceptibility genes or iii) the additive effect of both these mechanisms.

There are several cofounders in consanguinity - cancer risk besides infant size. Theoretically, the frequency of lethal cancer alleles is reduced by inbreeding in proportion to its duration and intensity. Inbreeding coexists with socioeconomic underdevelopment, which is associated with lower risk factors for breast cancer (e.g., earlier pregnancies, longer nursing, decreased use of alcohol and tobacco). In consanguineous populations, women generally marry earlier and earlier first pregnancies protects against breast cancer [36]. In some (but not all) studies, the daughters of consanguineous parents marry consanguineously more often, and they could be better protected by an earlier first pregnancy $[18,84]$. Polyandry, a theoretical determinant of baby size, varies between societies. Finally, a fathers' investment in offspring, another determinant of baby size, is a cultural trait that varies between societies, and it is a possible cofounder in BCR.

In future studies, for more clarity, the effect of autosomal gene conflict on birth size can be verified by comparing the parental coefficient of relatedness, the offspring coefficient of inbreeding and infant size from consanguineous and non-consanguineous families in the same population. The validity of genomic imprinting hypothesis of inbreeding can be tested by comparing the parental coefficient of relatedness of genomically imprinted genes and birth size. Furthermore, measuring growth hormones like IGF-2 in fetal blood and expression of developmental genes in the placenta (from women married to different types of cousins) would provide additional pieces of the puzzle. Then, we can be sure of the relative role of genomic imprinting in reducing the risk of breast cancer in inbred populations and add further to our understanding of carcinogenesis.

\section{Abbreviations \\ F: Coefficient of inbreeding; FBS: Father's brother's son; FSS: Father's sister's son; IGF-1: Insulin-like growth factor 1; MBS: Mother's brother's son; MENA: Middle East and North Africa; MSS: Mother's sister's son; R: Coefficient of relatedness; $R_{\mathrm{m}}$ : Coefficient of relatedness of maternally derived gnomically imprinted genes; $R_{\mathrm{p}}$ : Coefficient of relatedness of paternally derived gnomically imprinted genes; UAE: United Arab Emirates}

\section{Acknowledgements}

We thank Thomas Adrian, Starling Emerald and two reviewers for their useful comments.

\section{Funding}

This work was supported by a United Arab Emirates University grant (fund code 31 M26 to SD).
Availability of data and materials

Not applicable.

\section{Authors' contributions}

SD developed the hypothesis and concepts. Both SD and MMA wrote and revised the manuscript. Both authors read and approved the final manuscript.

Ethics approval and consent to participate

Not applicable.

Consent for publication

Not applicable.

Competing interests

The authors declare that they have no competing interests.

\section{Publisher's Note}

Springer Nature remains neutral with regard to jurisdictional claims in published maps and institutional affiliations.

\section{Author details}

'Department of Medicine, College of Medicine and Health Sciences, United Arab Emirates University, PO Box 17666, Al Ain, Abu Dhabi, UAE.

${ }^{2}$ Department of Pathology, California University of Science and Medicine, 217 E Club Center Drive, San Bernardino, CA 92408, USA.

Received: 17 August 2016 Accepted: 9 November 2017

Published online: 21 November 2017

\section{References}

1. Yan XS, Barnholtz-Sloan J, Chu X, Li L, Colonie R, Webster J, Smelser D, Patel N, Prichard J, Stark A. Adiposity, inflammation, genetic variants and risk of post-menopausal breast cancer findings from a prospective-specimencollection, retrospective-blinded-evaluation (PRoBE) design approach. Spring. 2013;2:638.

2. Sohail A, Kanwal N, Ali M, Sadia S, Masood Al, Ali F, Iqbal F, Crickmore N, Shaikh RS, Sayyed AH. Effects of glutathione-S-transferase polymorphisms on the risk of breast cancer: a population-based case-control study in Pakistan. Environ Toxicol Pharmacol. 2013 Mar;35(2):143-53.

3. Sinnett D, Kraijinovic M, Labuda D. Genetic susceptibility to childhood acute Iymphoblastic leukemia. Leuk Lymphoma. 2000;38:447-62.

4. Gao CM, Takezaki T, Wu JZ, Li ZY, Liu YT, Li SP, et al. Glutathione-Stransferases M1 (GSTM1) and GSTT1 genotype, smoking, consumption of alcohol and tea and risk of esophageal and stomach cancers: a case-control study of a high-incidence area in Jiangsu Province, China. Cancer Lett. 2002; 188(1-2):95-102.

5. Buch SC, Notani PN, Bhisey RA. Polymorphism at GSTM1, GSTM3 and GSTT1 gene loci and susceptibility to oral cancer in an Indian population. Carcinogenesis. 2002;23(5):803-7.

6. Stucker I, Hirvonen A. De W, I, Cabelguenne a, Mitrunen K, Cenee S et al. genetic polymorphisms of glutathione $\mathrm{S}$-transferases as modulators of lung cancer susceptibility. Carcinogenesis. 2002;23(9):1475-81.

7. Riley DJ, Liu CY, Lee WH. Mutations of $\mathrm{N}$-terminal regions render the retinoblastoma protein insufficient for functions in development and tumor suppression. Mol Cell Biol. 1997;17(12):7342-52.

8. Williams BO, Remington L, Albert DM, Mukai S, Bronson RT, Jacks T. Cooperative tumorigenic effects of germline mutations in Rb and p53. Nat Genet. 1994;7(4):480-4

9. Moser AR, Shoemaker AR, Connelly CS, Clipson L, Gould KA, Luongo C, et al. Homozygosity for the min allele of $A p C$ results in disruption of mouse development prior to gastrulation. Dev Dyn. 1995;203(4):422-33.

10. Ludwig T, Chapman DL, Papaioannou VE, Efstratiadis A. Targeted mutations of breast cancer susceptibility gene homologs in mice: lethal phenotypes of Brca1, Brca2, Brca1/Brca2, Brca1/p53, and Brca2/p53 nullizygous embryos. Genes Dev. 1997:11:1242-52.

11. Connor F, Bertwistle D, Mee PJ, Ross GM, Swift S, Grigorieva E, et al. Tumorigenesis and a DNA repair defect in mice with a truncating Brca2 mutation. Nat Genet. 1997;17:423-30. 
12. Denic S, Al-Gazali L. Breast cancer, consanguinity, and lethal tumor genes: simulation of BRCA1/2 prevalence over 40 generations. Int J Mol Med. 2002; 10(6):713-9.

13. Baris HN, Barnes-Kedar I, Toledano H, Halpern M, Hershkovitz D, Lossos A, Lerer I, Peretz T, Kariv R, Cohen S, Half EE, Magal N, Drasinover V, Wimmer K, Goldberg Y, Bercovich D, Levi Z. Constitutional mismatch repair deficiency in Israel: high proportion of founder mutations in MMR genes and consanguinity. Pediatr Blood Cancer. 2016;63(3):418-27.

14. Little CC. Hybridization and tumor formation in mice. Proc Natl Acad Sci. 1939:25:452.

15. Andervont HB. Influence of hybridization upon the occurrence of mammary tumors in mice. J Natl Cancer Inst. 1943;3:359-65.

16. Heston WE. Genetics: animal tumors. In: Becker FF, editor. Cancer 1 a comprehensive treatise. Etiology: chemical and physical carcinogenesis. New York: Plenum Press; 1975. p. 33-57.

17. Bener A, Denic S, Al-Mazrouei M. Consanguinity and family history of cancer in children with leukemia and lymphomas. Cancer. 2001:92(1):1-6.

18. Denic S, Bener A. Consanguinity decreases risk of breast cancer-cervical cancer unaffected. Br J Cancer. 2001;85(11):1675-9.

19. Denic S, Bener A, Sabri S, Khatib F, Milenkovic J. Parental consanguinity and risk of breast cancer: a population-based case-control study. Med Sci Monit. 2005;11(9):CR415-9.

20. Denic S, Frampton C, Nicholls MG. Risk of cancer in an inbred population. Cancer Detect Prev. 2007;31(4):263-9.

21. Bener A, Ayoubi HR, Ali Al, Al-Kubaisi A, Al-Sulaiti H. Does consanguinity lead to decreased incidence of breast cancer? Cancer Epidemiol. 2010;34(4):413-8.

22. Elalaoui SC, Jaouad IC, Laarabi FZ, Elgueddari BK. Low level of consanguinity in moroccan families at high risk of breast cancer. Asian Pac J Cancer Prev. 2013;14(2):723-6

23. Medimegh I, Troudi W, Omrane I, Ayari H, Uhrhummer N, Majoul H, Benayed F, Mezlini A, Bignon YJ, Sibille C, Elgaaied AB. Consanguinity protecting effect against breast cancer among Tunisian women: analysis of BRCA1 Haplotypes. Asian Pac J Cancer Prev. 2015;16(9):4051-5.

24. Gilani GM, Kamal S. Risk factors for breast cancer in Pakistani women aged less than 45 years. Ann Hum Biol. 2004;31(4):398-407.

25. Liede A, Malik IA, Aziz Z, Rios Pd Pde L, Kwan E, Narod SA. Contribution of BRCA1 and BRCA2 mutations to breast and ovarian cancer in Pakistan. Am J Hum Genet. 2002 Sep;71(3):595-606.

26. Shaukat U, Ismail M, Mehmood N. Epidemiology, major risk factors and genetic predisposition for breast cancer in the Pakistani population. Asian Pac J Cancer Prev. 2013;14(10):5625-9.

27. Shami SA, Qaisar R, Bittles AH. Consanguinity and adult morbidity in Pakistan. Lancet. 1991;338(8772):954

28. Assie G, LaFramboise T, Platzer P, Eng C. Frequency of germline genomic homozygosity associated with cancer cases. JAMA. 2008;299(12):1437-45.

29. Orloff MS, Zhang L, Bebek G, Eng C. Integrative genomic analysis reveals extended germline homozygosity with lung cancer risk in the PLCO cohort. PLoS One. 2012;7(2):e31975.

30. Sud A, Cooke R, Swerdlow AJ, Houlston RS. Genome-wide homozygosity signature and risk of Hodgkin lymphoma. Sci Rep. 2015;5:14315

31. Siraj AK, Khalak HG, Sultana M, Al-Rasheed M, Bavi P, Al-Sanea N, Al-Dayel F, Uddin S, Alkuraya FS, Al-Kuraya KS. Colorectal cancer risk is not associated with increased levels of homozygosity in Saudi Arabia. Genet Med. 2012:14:720-28.

32. Enciso-Mora V, Hosking FJ, Houlston RS. Risk of breast and prostate cancer is not associated with increased homozygosity in outbred populations. Eur J Hum Genet. 2010 Aug;18(8):909-14

33. Hosking FJ, Papaemmanuil E, Sheridan E, Kinsey SE, Lightfoot T, Roman E, Irving JA, Allan JM, Taylor M, Tomlinson IP, Greaves M, Houlston RS. Genome-wide homozygosity signatures and childhood acute lymphoblastic leukemia risk. Blood. 2010;115(22):4472-7.

34. Spain SL, Cazier JB, CORGI Consortium, Houlston R, Carvajal-Carmona L, Tomlinson I. Colorectal cancer risk is not associated with increased levels of homozygosity in a population from the United Kingdom. Cancer Res. 2009;69(18):7422-9.

35. Bittles AH, Black ML. Evolution in health and medicine Sackler colloquium: consanguinity, human evolution, and complex diseases. Proc Natl Acad Sci U S A. 2010;107(Suppl 1):1779-86.

36. Bittles $\mathrm{AH}$. Consanguinity in context. Cambridge, UK: Cambridge University Press; 2012

37. Denic S, Nagelkerke N, Agarwal MM. Choice of kin in consanguineous marriages: effects of altruism and ecological factors. Ann Hum Biol. 2010; 37(6):738-53.
38. Alawadi S, Ghabreau L, Alsaleh M, Abdulaziz Z, Rafeek M, Akil N, Alkhalaf M. P53 gene polymorphisms and breast cancer risk in Arab women. Med Oncol. 2011;28(3):709-15.

39. Alshatwi AA, Hasan TN, Shafi G, Alsaif MA, Al-Hazzani AA, Alsaif AA. A singlenucleotide polymorphism in the TP53 and MDM-2 gene modifies breast cancer risk in an ethnic Arab population. Fundam Clin Pharmacol. 2012; 26(3):438-43.

40. Chouchane L, Boussen H, Sastry KS. Breast cancer in Arab populations: molecular characteristics and disease management implications. Lancet Oncol. 2013;14(10):e417-24.

41. El-Harith e-HA, Abdel-Hadi MS, Steinmann D, Dork T. BRCA1 and BRCA2 mutations in breast cancer patients from Saudi Arabia. Saudi Med J. 2002; 23(6):700-4.

42. Denic S, Al-Gazali L. BRCA1 and BRCA2 mutations in breast cancer patients from Saudi Arabia. Saudi Med J. 2003:24(6):696. author reply 696-7

43. Bhurgri Y, Bhurgri A, Hassan SH, Zaidi SH, Rahim A, Sankaranarayanan R, et al. Cancer incidence in Karachi, Pakistan: first results from Karachi cancer registry. Int Cancer. 2000;85(3):325-9.

44. Baloch AH, Daud S, Raheem N, Lugman M, Ahmad A, Rehman A, Shuja J, Rasheed S, Ali A, Kakar N, Naseeb HK, Mengal MA, Awan MA, Wasim M, Baloch DM, Ahmad J. Missense mutations (p.H371Y, p.D438Y) in gene CHEK2 are associated with breast cancer risk in women of Balochistan origin. Mol Biol Rep. 2014;41(2):1103-7.

45. Rashid MU, Muhammad N, Faisal S, Amin A, Hamann U. Constitutional CHEK2 mutations are infrequent in early-onset and familial breast/ovarian cancer patients from Pakistan. BMC Cancer. 2013:13:312.

46. Huijts PE, Hollestelle A, Balliu B, Houwing-Duistermaat JJ, Meijers CM, Blom JC, Ozturk B, Krol-Warmerdam EM, Wijnen J, Berns EM, Martens JW, Seynaeve C, Kiemeney LA, van der Heijden HF, Tollenaar RA, Devilee P, van Asperen CJ. CHEK2*1100delC homozygosity in the Netherlands-prevalence and risk of breast and lung cancer. Eur J Hum Genet. 2014;22(1):46-51.

47. Denic S, Khatib F, Awad M, Karbani G, Milenkovic J. Cancer by negative heterosis: breast and ovarian cancer excess in hybrids of inbred ethnic groups. Med Hypotheses. 2005;64(5):1002-6.

48. Vrana PB, Matteson PG, Schmidt JV, Ingram RS, Joyce A, Prince KL, Dewey MJ, Tilghman SM. Genomic imprinting of a placental lactogen gene in Peromyscus. Dev Genes Evol. 2001;211(11):523-32.

49. Khongsdier R, Mukherjee N. Effects of heterosis on growth in height and its segments: a cross-sectional study of the Khasi girls in Northeast India. Ann Hum Biol. 2003;30(5):605-21.

50. Mumtaz G, Tamim H, Kanaan M, et al. Effect of consanguinity on birth weight for gestational age in a developing country. Am J Epidemiol. 2007:165:742-52.

51. Ozener B. Effect of inbreeding depression on growth and fluctuating asymmetry in Turkish young males. Am J Hum Biol. 2010;22(4):557-62

52. Ozener B, Graham JH. Growth and fluctuating asymmetry of human newborns: influence of inbreeding and parental education. Am J Phys Anthropol. 2014:153(1):45-51.

53. Lunde A, Melve KK, Gjessing HK, Skjaerven R, Irgens LM. Genetic and environmental influences on birth weight, birth length, head circumference, and gestational age by use of population-based parent-offspring data. Am J Epidemiol. 2007:165(7):734-41.

54. Kramer MS. Determinants of low birth weight: methodological assessment and meta-analysis. Bull World Health Organ. 1987:65(5):663-737.

55. Von Bonsdorff MB, Muller M, Aspelund T, et al. Persistence of the effect of birth size on dysglycaemia and type 2 diabetes in old age: AGES-Reykjavik study. Age (Dordr). 2012;35:1401-9.

56. Vaag $A$, Jensen $C B$, Poulsen $P$, et al. Metabolic aspects of insulin resistance in individuals born small for gestational age. Horm Res. 2006;65(Suppl.3):137-43.

57. Ekbom A, Trichopoulos D, Adami HO, Hsieh CC, Lan SJ. Evidence of prenatal influences on breast cancer risk. Lancet. 1992:340:1015-8.

58. Michels KB, Trichopoulos D, Robins JM, et al. Birth weight as a risk factor for breast cancer. Lancet. 1996:348:1542-6.

59. Vatten LJ, Maehle BO, Lund Nilsen TI, et al. Birth weight as a predictor of breast cancer: a case-control study in Norway. Brit J Cancer. 2002;86:89-91.

60. McCormack VA, dos Santos SI, Koupil I, Leon DA, Lithell HO. Birth characteristics and adult cancer incidence: Swedish cohort of over 11,000 men and women. Int J Cancer. 2005 Jul 1;115(4):611-7.

61. Silva Idos S, De Stavola B, McCormack V. Collaborative group on pre-Natal risk factors and subsequent risk of breast cancer. Birth size and breast cancer risk: re-analysis of individual participant data from 32 studies. PLoS Med. 2008;5(9):e193. 
62. Hurley S, Goldberg D, Von Behren J, Quach T, Layefsky M, Reynolds P. Birth size and breast cancer risk among young California-born women. Cancer Causes Control. 2011;22(10):1461-70.

63. Sandvei MS, Lagiou P, Romundstad PR, Trichopoulos D, Vatten L. Size at birth and risk of breast cancer: update from a prospective population-based study. Eur J Epidemiol. 2015;30(6):485-92.

64. Trichopoulos D. Hypothesis: does breast cancer originate in utero? Lancet. 1990;335:939-40.

65. Trichopoulos D, Lipman R. Mammary gland mass and breast cancer risk. Epidemiology. 1992;3:523-6.

66. Trichopoulos D, Lagiou P, Adami HO. Towards an integrated model for breast cancer etiology: the crucial role of the number of mammary tissuespecific stem cells. Breast Cancer Res. 2005;7(1):13-7.

67. Tamimi RM, Eriksson L, Lagiou P, Czene K, Ekbom A, Hsieh CC, Adami HO, Trichopoulos D, Hall P. Birth weight and mammographic density among postmenopausal women in Sweden. Int J Cancer. 2010;126(4):985-91.

68. Strohsnitter WC, Savarese TM, Low HP, Chelmow DP, Lagiou P, Lambe M, Edmiston K, Liu Q, Baik I, Noller KL, Adami HO, Trichopoulos D, Hsieh CC. Correlation of umbilical cord blood haematopoietic stem and progenitor cell levels with birth weight: implications for a prenatal influence on cancer risk. Br J Cancer. 2008;98(3):660-3.

69. Gluckman PD, Johnson-Barrett JJ, Butler JH, Edgar BW, Gunn TR. Studies of insulin-like growth factor -1 and $-\|$ by specific radioligand assays in umbilical cord blood. Clin Endocrinol. 1983;19(3):405-13.

70. Lagiou P, Hsieh CC, Lipworth L, Samoli E, Okulicz W, Troisi R, Xu B, Hall P, Ekbom A, Adami HO, Trichopoulos D. Insulin-like growth factor levels in cord blood, birth weight and breast cancer risk. Br J Cancer. 2009;100(11):1794-8.

71. Baik I, Devito WJ, Ballen K, Becker PS, Okulicz W, Liu Q, Delpapa E, Lagiou P, Sturgeon S, Trichopoulos D, Quesenberry PJ, Hsieh CC. Association of fetal hormone levels with stem cell potential: evidence for early life roots of human cancer. Cancer Res. 2005;65(1):358-63.

72. Moore GE, Ishida M, Demetriou C, Al-Olabi L, Leon $\sqcup$, Thomas AC, AbuAmero S, Frost JM, Stafford JL, Chaoqun Y, Duncan AJ, Baigel R, Brimioulle M, Iglesias-Platas I, Apostolidou S, Aggarwal R, Whittaker JC, Syngelaki A, Nicolaides KH, Regan L, Monk D, Stanier P. The role and interaction of imprinted genes in human fetal growth. Philos Trans R Soc Lond Ser B Biol Sci. 2015:370(1663):20140074

73. Demetriou C, Abu-Amero S, Thomas AC, Ishida M, Aggarwal R, et al. Paternally expressed, imprinted insulin-like growth Factor-2 in chorionic Villi correlates significantly with birth weight. PLoS One. 2014;9(1):e85454.

74. McMinn J, Wei M, Schupf N, Cusmai J, Johnson EB, et al. Unbalanced placental expression of imprinted genes in human intrauterine growth restriction. Placenta. 2006;27:540-9.

75. Apostolidou S, Abu-Amero S, O'Donoghue K, Frost J, Olafsdottir O, et al. Elevated placental expression of the imprinted PHLDA2 gene is associated with low birth weight. J Mol Med. 2007:85:379-87.

76. Feng S, Jacobsen SE, Reik W. Epigenetic reprogramming in plant and animal development. Science. 2010;330(6004):622-7.

77. Keverne EB, Curley JP. Epigenetics, brain evolution and behaviour. Front Neuroendocrinol. 2008:29(3):398-412.

78. Trivers R, Burt A. In: Ohlsson R, editor. Kinship and genomic imprinting. In genomic imprinting. An interdisciplinary approach. Berlin: Springer Verlag; 1999. p. 1-21.

79. Haig D. The kinship theory of imprinting. Annu Rev Ecol Syst. 2000;31:9-32.

80. Haig D. Genetic conflicts in human pregnancy. Q Rev Biol. 1993;68(4):495-532.

81. Burt A, Trivers R. Genes in conflict: the biology of selfish genetic elements. Cambridge: Harvard University Press; 2008.

82. Aro SO, Adejumo DO. The effect of social groups on reproductive performance of Wistar rats. J Anim Plant Sci. 2010;6:637-44.

83. Peto J. Cancer epidemiology in the last century and the next decade. Nature. 2001:411(6835):390-5.

84. Bakoush O, Bredan A, Denic S. Kin and non-kin marriages and family structure in rich tribal society. J Biosoc Sci. 2016;48(6):797-805.

\section{Submit your next manuscript to BioMed Central and we will help you at every step:}

- We accept pre-submission inquiries

- Our selector tool helps you to find the most relevant journal

- We provide round the clock customer support

- Convenient online submission

- Thorough peer review

- Inclusion in PubMed and all major indexing services

- Maximum visibility for your research

Submit your manuscript at www.biomedcentral.com/submit
) Biomed Central 